\title{
KETIDAKEFEKTIFAN KALIMAT PADA CAPTION INSTAGRAM MAHASISWA FAKULTAS PERTANIAN UNIVERSITAS WINAYA MUKTI
}

\author{
Lilis Amaliah Rosdiana \\ Universitas Winaya Mukti \\ Surel: lilisamaliah87@gmail.com
}

\begin{abstract}
Abstrak
Lahirnya teknologi kerap membuat perubahan pada pola kehidupan masyarakat. Tidak bisa dipungkiri lagi perkembangan media ikut juga berperan aktif dalam perubahan gaya hidup seseorang baik media elektronik, cetak maupun online. Mahasiswa Fakultas Pertanian seringkali membagikan foto-foto kegiatan, liburan, ataupun situasi mereka berada saat itu. Namun, penulis melihat banyak sekali kalimat caption (keterangan) yang mengindahkan tentang kalimat efektif. Penelitian ini mempunyai tujuan untuk mengetahui gambaran umum ketidakefektifan kalimat pada caption instagram Mahasiswa Fakultas Pertanian Universitas Winaya Mukti dan mengetahui faktor ketidakefektifan kalimat apa saja yang ada pada caption instagram Mahasiswa Fakultas Pertanian Universitas Winaya Mukti. Penelitian berfokus pada faktor-faktor ketidakefektifan kalimat yang terdapat pada caption instagram yang dituliskan oleh Mahasiswa Fakultas Pertanian Universitas Winaya Mukti. Metode penelitian yang digunakan adalah penelitian kualitatif dengan teknik analisis deskriptif. Data diambil selama tujuh hari yaitu 9-15 September 2018. Hasil penelitian menunjukan data: terdapat 50 data caption instagram yang berhasil dikumpulkan dalam waktu tujuh hari tersebut. Namun hanya 34 data mengalami ketidakefektifan kalimat dengan rincian sebagai berikut: 13 pengaruh bahasa asing, 3 pleonasme, 5 ambiguitas, 1 kesalahan nalar, 3 ketidakjelasan unsur inti kalimat, 4 pengaruh bahasa daerah, 3 penggunaan kata tidak baku, 1 kemubaziran preposisi kata, 1 ketidakjelasan makna kata dan tidak terdapat kalimat yang mengandung ketidaktepatan bentuk kata dan kontaminasi.
\end{abstract}

Kata kunci: ketidakefektifan kalimat, caption instagram, mahasiswa.

\section{Jurnal Abstract
Penahasa, Sastra
Indonesia dan Daerah}

Technology often makes changes to the pattern of people's lives. It is undeniable that the development of media also plays an active role in changing one's lifestyle, both electronic, print and online. Faculty of Agriculture students often share photos of activities, vacations, or their situation at that time. However, the author sees many sentences that are not in accordance with the moral rules. This study is aimed to find out the general picture of sentence ineffectiveness on the Instagram captions written by the students of Agriculture Faculty of Winaya Mukti University. Moreover, the factors of sentence ineffectiveness are also investigated in this study. This research uses qualitative method with descriptive analysis technique. There are 50 Instagram captions analyzed in this research that were posted from 9 to 15 September 2018. The results show that, from all analyzed data, there are only 34 captions that are 
considered to have sentence ineffectiveness with the following details: 13 foreign language interferences, 3 pleonasms, 5 ambiguities, 1 logical reasoning, 3 unclear core elements of the sentence, 4 regional language interferences, 3 non-standard word usages, 1 prepositional redundancy, 1 ambiguity of word meaning. There are no sentences that contain inaccuracy of word form and contamination.

Keywords: sentences ineffectiveness, Instagram caption, college students.

\section{PENDAHULUAN}

Perkembangan teknologi informasi membawa sebuah perubahan dalam masyarakat. Lahirnya media sosial menjadikan pola perilaku masyarakat mengalami pergeseran baik budaya, etika dan norma yang ada. Indonesia dengan jumlah penduduk yang besar dengan berbagai kultur suku, ras dan agama yang beraneka ragam memiliki banyak sekali potensi perubahan sosial. Dari berbagai kalangan dan usia hampir semua masyarakat Indonesia memiliki dan menggunakan media sosial sebagai salah satu sarana guna memperoleh dan menyampaikan informasi ke publik.

Majunya teknologi dan arus informasi membuat masyarakat Indonesia lebih terbuka pada pengetahuan global. Tidak bisa dipungkiri lagi perkembangan media ikut juga berperan aktif dalam perubahan gaya hidup seseorang baik media elektronik, cetak maupun online. Media sosial yang mena-
warkan aplikasi khusus dan dikemas secara menarik juga membantu penggunanya untuk terus mengikuti perkembangan media sosial itu sendiri. Media sosial menawarkan berbagai kemudahan dalam penyebarluasan dan penerimaan informasi. Mudah dan cepat juga menjadi andalan dari media sosial itu sendiri. Hal ini menyebabkan terjadi- nya perubahan-perubahan sosial baik secara positif maupun negatif.

Satu orang pastinya tak hanya memiliki satu media sosial. Bisa jadi setiap orang memiliki hampir seluruh aplikasi media sosial, sebut saja facebook dan instagram. Walaupun mungkin saja setiap orang memiliki lebih dari dua media sosial tersebut. Tetapi yang sedang banyak diminati saat ini adalah facebook dan instagram.

Saat ini, hidup masyarakat tak bisa lepas dari media sosial. Apa yang ada di pikirannya, apa yang sedang dilakukannya, dan apa rencana hidupnya yang akan datang mereka tuangkan dalam media sosial tersebut. Seperti instagram, orang-orang saat ini berlomba-lomba hunting tempat wisata, tempat liburan, bahkan tempat-tempat makan dari yang pinggir jalan sampai hotel mewah tak luput dari bidikan si pemburu foto hanya untuk memposting sebuah foto dalam instagram.

dikan BahInstagram sendiri merupakan tempat untuk mengunggah dan berbagi foto-foto kepada pengguna lainnya. Sistem sosial dalam instagram adalah dengan menjadi pengikut akun pengguna instagram lainnya. Dengan demikian komunikasi antara sesama pengguna akun dapat terjalin dengan memberikan tanda suka dan juga mengomentari foto-foto yang telah diunggah oleh pengguna lainnya. Pengikut juga menjadi salah 
satu unsur yang penting, di mana jumlah tanda suka dari para pengikut sangat mempengaruhi apakah foto tersebut dapat menjadi sebuah foto yang populer atau tidak.

Oleh karena itu, masyarakat zaman sekarang berlomba mengunggah foto sedemikian rupa agar mendapatkan banyak like hingga menjadi foto yang populer. Banyak dari mereka turut serta menuliskan sebuah "caption" untuk menceritakan maksud foto tersebut. Ada yang memang sesuai dengan fotonya, ada juga yang menuliskan kata-kata bijak sebagai penghias fotonya.

Caption. Kata "caption" terdengar tidak asing di telinga kita. Seiring berkembangnya media sosial Instagram, kalimat caption tidak pernah terlepas dari unggahan foto yang menyertainya.

Menurut Kontenesia (2018), caption adalah tulisan singkat yang menerangkan kegiatan dalam foto atau gambar dan dituliskan di bawah foto atau gambar tersebut. Pendapat lainnya mengatakan bahwa caption adalah tulisan singkat atau keterangan gambar yang bertujuan memberikan penekanan maksud selain visualisasi pesan yang sudah nampak.

Namun, mereka terbiasa memberi caption dengan bahasa yang tidak baku, kadang memakai bahasa daerah juga kadang menggunakan bahsa asing dengan kalimat tidak efektif. Di sini peneliti ingin mengetahui seberapa banyak mahasiswa fakultas pertanian yang memberi caption pada postingan akun instagram yang memiliki ketidakefektifan kalimat.

Menurut Putrayasa (2007:57), ketidakefektifan kalimat dapat disebabkan oleh beberapa faktor. Faktor-faktor tersebut meliputi:

\section{Kontaminasi atau Kerancuan}

Kontaminasi ialah suatu gejala bahasa yang dalam bahasa Indonesia diistilahkan dengan kerancuan. Rancu artinya 'kacau'. Jadi, kerancuan artinya 'kekacauan'. Yang dirancukan ialah susunan, perserangkaian, dan penggabungan. Dua yang masingmasing berdiri sendiri disatukan dalam satu perserangkaian baru yang tidak berpasangan. Hasilnya ialah kerancuan.

\section{Pleonasme}

Pleonasme berarti pemakaian kata-kata yang berlebihan. Ada penggunaan dua kata yang searti yang sebenarnya tidak perlu karena menggunakan salah satu di antara kedua kata itu sudah cukup.

\section{Ambiguitas atau keambiguan}

Kalimat yang memenuhi ketentuan tata bahasa, tetapi masih menimbulkan tafsiran ganda tidak termasuk kalimat efektif.

\section{Ketidakjelasan Unsur Inti Kali- mat}

Suatu kalimat yang baik memang harus mengandung unsur-unsur yang lengkap. Dalam hal ini, kelengkapan unsur kalimat itu sekurang-kurangnya harus memenuhi dua hal, yaitu subjek dan predikat. Jika predikat kalimat itu berupa kata kerja transitif, unsur kalimat yang disebut onjek juga harus hadir Unsur lain, yakni keterangan, kehadirannya bersifat sekunder atau tidak terlalu dipentingkan.

\section{Kemubaziran Preposisi dan Kata}

Ketidakefektifan kalimat sering disebabkan oleh pemakaian kata depan (preposisi) yang tidak perlu. Kata depan dari misalnya pada kata: "rumah dari paman saya". Struktur bahasa Indonesia tidak demikian, cukup dikatakan "rumah paman saya". 


\section{Kesalahan Nalar}

Nalar menentukan apakah kalimat yang kita tuturkan adalah kalimat yang logis atau tidak. Nalar ialah aktivitas yang memungkinkan seseorang berpikir logis. Pikiran yang logis ialah pikiran yang masuk akal yang berterima.

Dalam tuturan sehari-hari tidak jarang kita mendengar kalimat yang dituturkan orang dapat juga dipahami, padahal jika diteliti benar, akan tampak bahwa kata-kata yang digunakan dalam kalimat itu tidak menunjukan hubungan makna yang logis.

\section{Ketidaktepatan Bentuk Kata}

Seperti kita ketahui, bahwa awalan pe- tidak mendapat bunyi apabila dilekatkan pada kata dasar berkonsonan /1/ atau /r/. Namun, dewasa ini banyak yang kita jumpai bentukan kata yang menyimpang (tidak tepat) dari aturan yang ada. Misalnya pada kata "pengrusakan" yang seharusnya "perusakan". Begitu juga dengan "pengluasan" yang seharusnya "peluasan".

\section{Ketidaktepatan Makna Kata}

Jika sebuah kata tidak dipahami maknanya, pemakaiannya pun mungkin tidak akan tepat. Hal itu tidak akan menimbulkan keganjilan, kekaburan, dan salah tafsir. Jurnal llmiah Hal-hal yang menyangkut masalah hubungan kata dengan maknanya:
a) konsep makna
b) homonimi
c) polisemi
d) hipernimi dan hiponimi
e) sinonim
f) antonim
g) dan konotasi

\section{Pengaruh Bahasa Daerah}

Banyak kata dari bahasa daerah masuk ke dalam bahasa Indonesia, memperkaya perbendaharaan katakatanya. Kata-kata, seperti heboh, becus, lumayan, mendingan, gagasan, gembleng, ganyang, cemooh, semarak, bobot, macet, seret, awet, sumber, dan melempem, semua berasal dari bahasa daerah.

\section{Pengaruh Bahasa Asing}

Dalam perkembangannya, bahasa Indonesia tidak terlepas dari pengaruh bahasa lain, bahasa asing ataupun bahasa asing. Pengaruh itu di satu sisi dapat memperkaya khazanah bahasa Indonesia, tetapi di sisi lain dapat juga mengganggu kaidah tata bahasa Indonesia sehingga menimbulkan ketidakefektifan kalimat.

Berdasarkan uraian di atas, peneliti melihat sangat banyak ketidakefektifan kalimat yang dilakukan mahasiswa ketika memberi caption instagram. Maka, peneliti mengambil judul penelitian, "Ketidakefektifan Kalimat pada Caption Instagram Mahasiswa Fakultas Pertanian Universitas Winaya Mukti”.

Rumusan masalah pada penelitian ini adalah sebagai berikut: (1) Bagaimana gambaran umum ketidakefektifan kalimat pada caption instagram Mahasiswa Fakultas Pertanian Universitas Winaya Mukti? (2) Faktor ketidakefektifan kalimat apa saja yang ada pada caption instagram Mahasiswa Fakultas Pertanian Universitas Winaya Mukti?

Adapun tujuan dari penelitian ini adalah (1) Mengetahui gambaran umum ketidakefektifan kalimat pada caption instagram Mahasiswa Fakultas Pertanian Universitas Winaya Mukti, (2) Mengetahui faktor ketidakefektifan kalimat apa saja yang 
ada pada caption instagram Mahasiswa Fakultas Pertanian Universitas Winaya Mukti.

\section{METODE}

Metode penelitian yang digunakan adalah penelitian kualitatif dengan teknik analisis deskriptif. Di mana peneliti menggambarkan dan menguraikan faktor-faktor ketidakefektifan kalimat apa saja yang dituliskan mahasiswa pada caption instagramnya.

Peneliti sebagai instrumen utama dalam penelitian ini. Data diambil selama tujuh hari yaitu 9-15 September 2018. Metode pengumpulan data yang digunakan adalah metode simak dengan teknik lanjutan catat. Karena data dalam penelitian ini berupa data tertulis, maka metode simak dilakukan dengan cara membaca dengan seksama kemudian diikuti dengan teknik catat untuk mengklasifikasikan data yang relevan.

\section{HASIL DAN PEMBAHASAN}

\section{Gambaran Umum}

Penelitian berfokus pada ketidakefektifan kalimat pada caption instagram mahasiswa Fakultas Pertanian Universitas Winaya Mukti. Pengumpulan data diambil secara alamiah bersumber dari caption instagram yang mahasiswa posting Data diambil selama tujuh hari yaitu tanggal 9-15 September 2018. Hasil penelitian menunjukan data: terdapat 50 data caption instagram yang berhasil dikumpulkan dalam waktu tujuh hari tersebut. Namun hanya 34 data mengalami ketidakefektifan kalimat dengan rincian sebagai berikut: 13 pengaruh bahasa asing, 3 pleonasme, 5 ambiguitas, 1 kesalahan nalar, 3 ketidakjelasan unsur inti kalimat, 4 pengaruh bahasa daerah, 3 penggunaan kata tidak baku, 1 kemubaziran preposisi kata, dan 1 ketidakjelasan makna kata.

Berikut penulis sajikan persentase data ketidakefektifan kalimat pada caption instagram Mahasiswa Fakultas Pertanian Universitas Winaya Mukti.

\section{Tabel 1}

Persentase Data Ketidakefektifan

Kalimat pada Caption Instagram

Mahasiswa Fakultas Pertanian Universitas Winaya Mukti

\begin{tabular}{|c|c|c|c|}
\hline No. & $\begin{array}{c}\text { Jenis } \\
\begin{array}{c}\text { Ketidakefektifan } \\
\text { Kalimat }\end{array} \\
\end{array}$ & $\begin{array}{c}\text { Banyak } \\
\text { Data }\end{array}$ & $\begin{array}{c}\text { Per- } \\
\text { sentasi } \\
(\%)\end{array}$ \\
\hline 1. & Kontaminasi & 0 & 0 \\
\hline 2. & Pleonasme & 3 & 8,82 \\
\hline 3. & Ambiguitas & 5 & 14,71 \\
\hline 4. & $\begin{array}{l}\text { Ketidakjelasan } \\
\text { Unsur Inti } \\
\text { Kalimat }\end{array}$ & 3 & 8,82 \\
\hline 5. & $\begin{array}{l}\text { Kemubaziran } \\
\text { Preposisi Kata }\end{array}$ & 1 & 2,93 \\
\hline 6. & Kesalahan Nalar & 1 & 2,93 \\
\hline 7. & $\begin{array}{l}\text { Ketidaktepatan } \\
\text { Bentuk Kata }\end{array}$ & 0 & 0 \\
\hline 8. & $\begin{array}{l}\text { Ketidaktepatan } \\
\text { Makna Kata }\end{array}$ & 1 & 2,93 \\
\hline 9. & $\begin{array}{l}\text { Penggunaan Kata } \\
\text { Tidak Baku }\end{array}$ & 3 & 8,82 \\
\hline 10. & $\begin{array}{l}\text { Pengaruh Bahasa } \\
\text { Asing }\end{array}$ & 13 & 38,23 \\
\hline 11. & $\begin{array}{l}\text { Pengaruh Bahasa } \\
\text { Daerah }\end{array}$ & 4 & 11,76 \\
\hline Bah & sa, SaTotal & 34 & \\
\hline
\end{tabular}

\section{dikar Bahdsa, SaTotal}

Berdasarkan tabel di atas, data caption yang paling banyak mengalami ketidakefektifan kalimat adalah pengaruh bahasa asing. Sebanyak 38,23\% mahasiswa menulis caption instagram menggunakan bahasa Inggris. Kedua terbesar itu sebanyak $14,71 \%$ yaitu ambiguitas. Lalu yang ketiga sebanyak 11,76\% pengaruh bahasa daerah. Kemudian 
sama banyak yaitu masing-masing sebanyak $8,82 \%$ adalah pleonasme, ketidakjelasan unsur inti kalimat, dan penggunaan bahasa daerah. Setelah itu masing-masing sebanyak 2,93\% adalah kemubaziran preposisi kata, kesalahan nalar, dan ketidaktepatan bentuk kata. Tidak terdapat kalimat yang mengandung ketidaktepatan bentuk kata dan kontaminasi sebanyak $0 \%$.

\section{Analisis Ketidakefektifan}

Kalimat pada Caption

Instagram Mahasiswa Fakultas Pertanian Universitas Winaya

\section{Mukti}

Berikut penulis sajikan analisis data ketidakefektifan kalimat pada caption instagram Mahasiswa Fakultas Pertanian Universitas Winaya Mukti.

Tabel 2.

Analisis Data Ketidakefektifan

Kalimat pada Caption Instagram

Mahasiswa Fakultas Pertanian

Universitas Winaya Mukti

\begin{tabular}{|c|c|c|c|}
\hline No. & $\begin{array}{c}\text { Caption } \\
\text { Instagram }\end{array}$ & $\begin{array}{c}\text { Jenis } \\
\text { Ketidak- } \\
\text { efektifan } \\
\text { Kalimat }\end{array}$ & $\begin{array}{l}\text { Analisis dan } \\
\text { Perbaikan }\end{array}$ \\
\hline 1. & $\begin{array}{l}\text { Only } \\
\text { silence } \\
\text { make me } \\
\text { happy }\end{array}$ & $\begin{array}{l}\text { Pengaruh } \\
\text { bahasa } \\
\text { asing }\end{array}$ & $\begin{array}{l}\text { Only silence } \\
\text { make me } \\
\text { happy dirnal II } \\
\text { kurang tepat.nes } \\
\text { seharusnya } \\
\text { Only silence } \\
\text { can make me } \\
\text { happy dan } \\
\text { penulisannya } \\
\text { pun harus } \\
\text { ditulis miring. } \\
\text { Atau jika } \\
\text { diubah ke } \\
\text { dalam bahasa } \\
\text { Indonesia } \\
\text { menjadi } \\
\text { 'Hanya dengan }\end{array}$ \\
\hline
\end{tabular}

\begin{tabular}{|c|c|c|c|}
\hline No. & $\begin{array}{c}\text { Caption } \\
\text { Instagram }\end{array}$ & $\begin{array}{c}\text { Jenis } \\
\text { Ketidak- } \\
\text { efektifan } \\
\text { Kalimat }\end{array}$ & $\begin{array}{l}\text { Analisis dan } \\
\text { Perbaikan }\end{array}$ \\
\hline & & & $\begin{array}{l}\text { diam saya bisa } \\
\text { bahagia.' }\end{array}$ \\
\hline 2. & $\begin{array}{l}\text { Hepi } \\
\text { weding } \\
\text { fren... }\end{array}$ & $\begin{array}{l}\text { Pengaruh } \\
\text { bahasa } \\
\text { asing }\end{array}$ & $\begin{array}{l}\text { Hepi weding } \\
\text { fren.... } \\
\text { seharusnya } \\
\text { Happy } \\
\text { wedding my } \\
\text { friend.... atau } \\
\text { diubah ke } \\
\text { dalam bahasa } \\
\text { Indonesia } \\
\text { menjadi } \\
\text { 'Selamat } \\
\text { menikah } \\
\text { temanku.' }\end{array}$ \\
\hline ah & asa, Sastra & $\begin{array}{l}\text { Pengaruh } \\
\text { bahasa } \\
\text { asing }\end{array}$ & $\begin{array}{l}\text { Sist n Broth } \\
\text { seharusnya } \\
\text { Sister and } \\
\text { Brother, atau } \\
\text { diubah ke } \\
\text { dalam bahasa } \\
\text { Indonesia } \\
\text { menadi "Adik } \\
\text { dan Kakak" } \\
\text { karena dalam } \\
\text { foto tersebut } \\
\text { yang disebut } \\
\text { 'sist' itu } \\
\text { terlihat lebih } \\
\text { kecil. Maka } \\
\text { dapat } \\
\text { disimpulkan } \\
\text { bahwa anak } \\
\text { 'sist' tersebut } \\
\text { adalah adik } \\
\text { dari anak laki- } \\
\text { laki yang } \\
\text { disebut 'broth'. }\end{array}$ \\
\hline do4! D & $\begin{array}{l}\text { Inilah para } \\
\text { perempuan- } \\
\text { perempuan } \\
\text { pejuang } \\
\text { tugas akhir. }\end{array}$ & $\begin{array}{l}\text { Pleonas } \\
\text { me }\end{array}$ & $\begin{array}{l}\text { Inilah para } \\
\text { perempuan- } \\
\text { perempuan } \\
\text { pejuang tugas } \\
\text { akhir } \\
\text { seharusnya } \\
\text { Inilah } \\
\text { perempuan- } \\
\text { perempuan } \\
\text { pejuang tugas } \\
\text { akhir. } \\
\text { Atau } \\
\text { Inilah para } \\
\text { perempuan }\end{array}$ \\
\hline
\end{tabular}




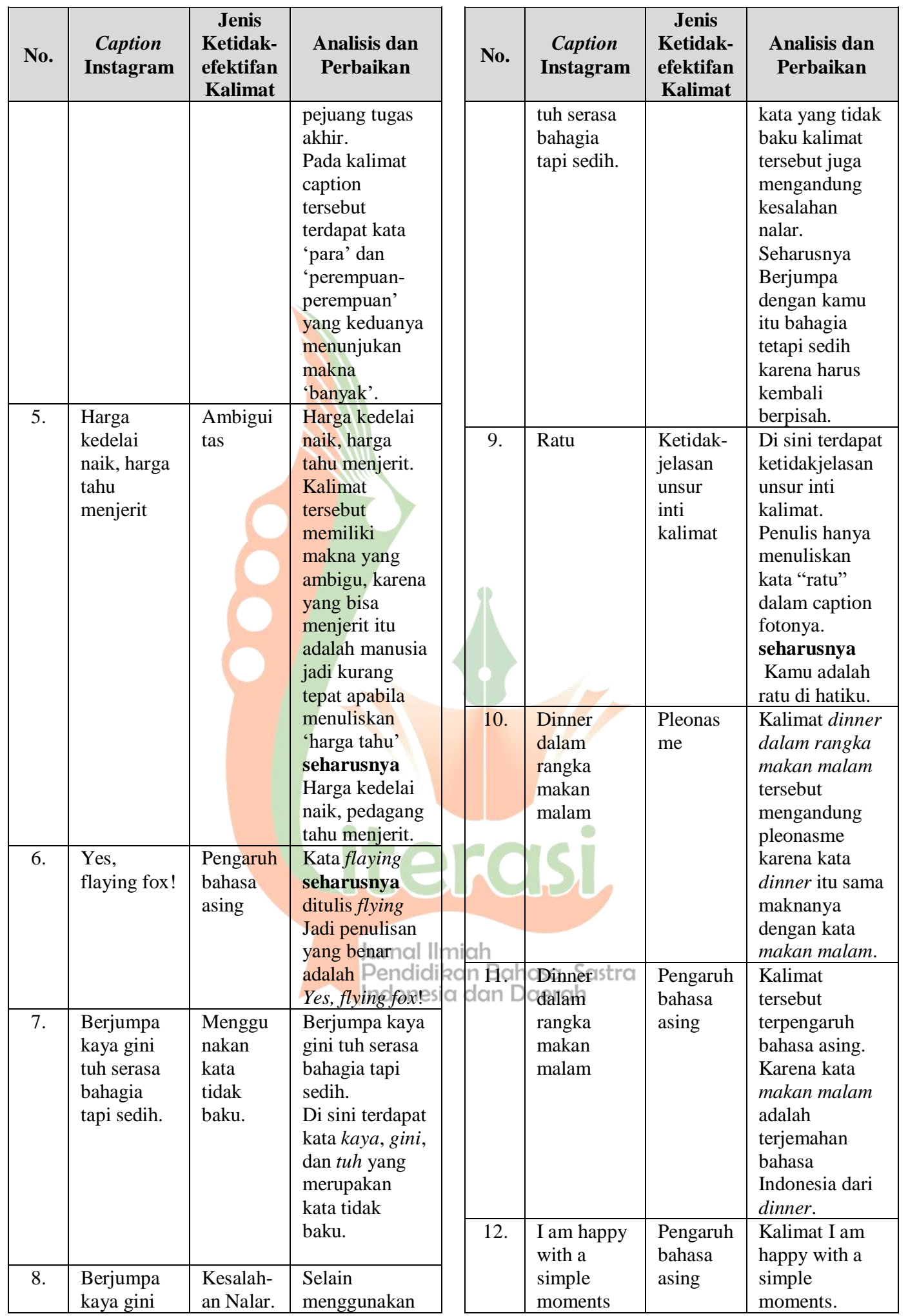




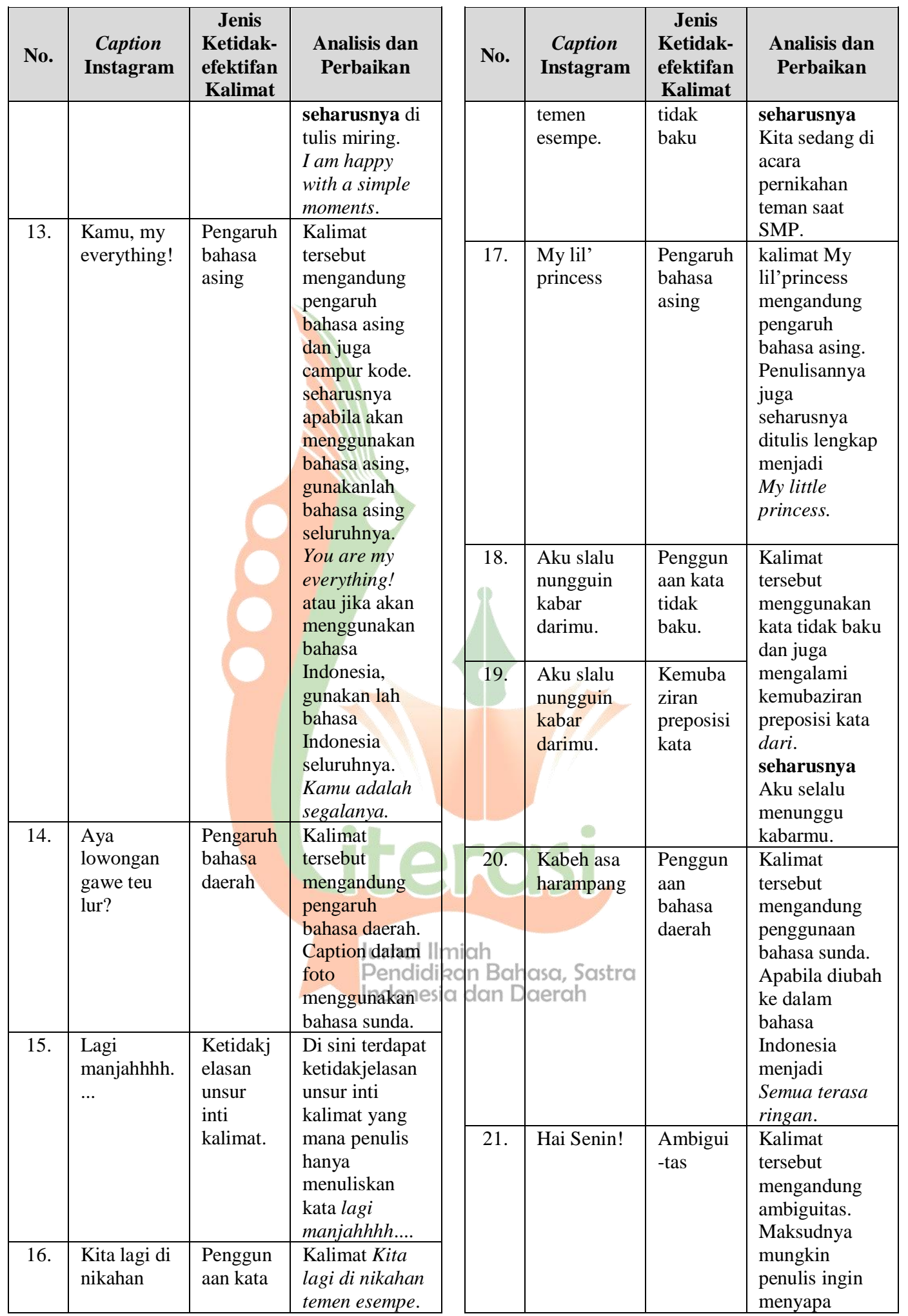




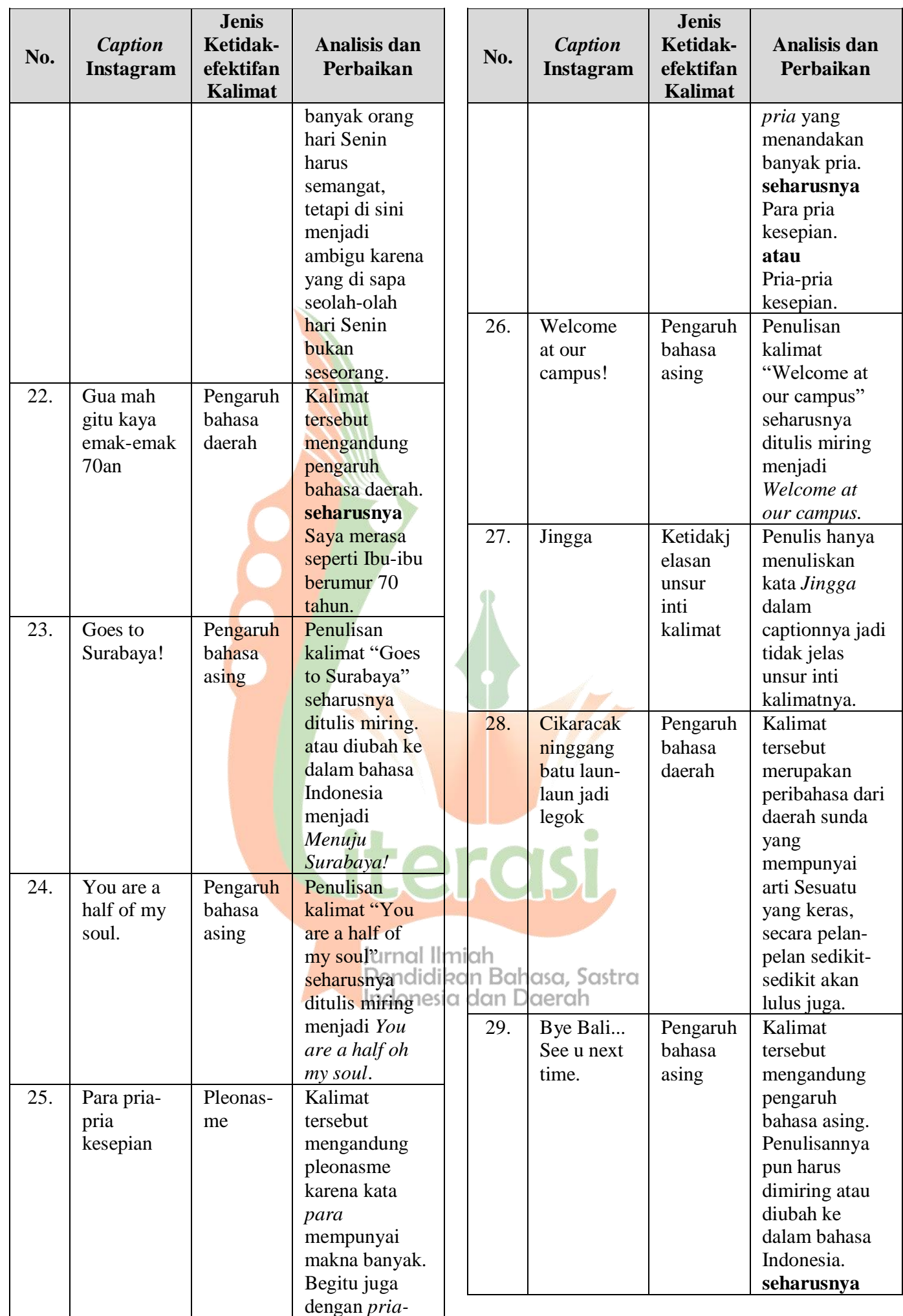




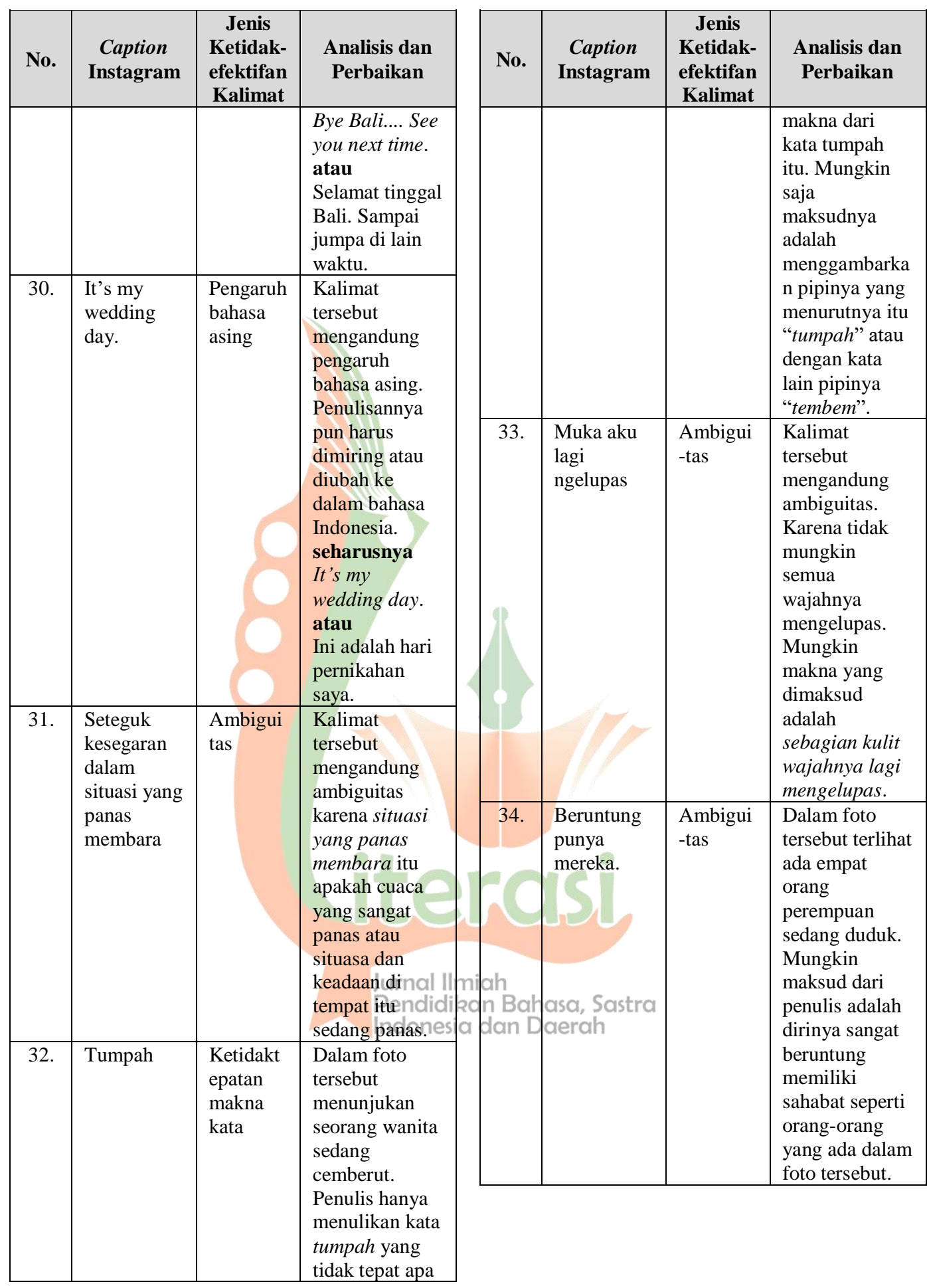




\section{PENUTUP}

\section{Simpulan}

Berdasarkan uraian di atas, hasil penelitian menunjukan data: terdapat 50 data caption instagram yang berhasil dikumpulkan dalam waktu tujuh hari tersebut. Namun hanya 34 data mengalami ketidakefektifan kalimat dengan rincian sebagai berikut: 13 data atau sebanyak 38,23\% pengaruh bahasa asing, 3 data atau sebanyak $8,82 \%$ pleonasme, 5 dan atau $14,71 \%$ ambiguitas, 1 data atau $2,93 \%$ kesalahan nalar, 3 data atau $8,82 \%$ ketidakjelasan unsur inti kalimat, 4 data atau $11,76 \%$ pengaruh bahasa daerah, 3 data atau $8,83 \%$ penggunaan kata tidak baku, 1 data atau 2,93\% kemubaziran preposisi kata, dan 1 data atau 2,93\% ketidakjelasan makna kata. Tidak terdapat kalimat yang mengandung ketidaktepatan bentuk kata dan kontaminasi sebanyak $0 \%$.

Berdasarkan hasil presentasi di atas, kita bisa melihat caption instagram Mahasiswa Fakultas Pertanian Universitas Winaya Mukti mengalami ketidakefektifan kalimat yang paling banyak adalah dari faktor pengaruh bahasa asing, kemudian di posisi kedua yaitu ambiguitas. Posisi ketiga ada tiga jenis ketidakefektifankalimat yang sama banyak, yaitu pleonasme, ketidakjelasan unsur inti kalimat, dan penggunaan bahasa daerah. Kemudian posisi berikutnya diikuti oleh kemubaziran preposisi kata, kesalahan nalar, dan ketidaktepatan bentuk kata. Dan yang terakhir di duduki oleh ketidaktepatan bentuk kata dan kontaminasi karena memang tidak ada caption instagram yang mengandung faktor ketidakefektifan kalimat.
Melihat hasil analisis dan pembahasan dalam penelitian ini, bukan tidak mungkin bahwa caption instagram memang didominasi oleh penggunaan bahasa asing. Di sini, seharusnya yang membuat caption instagram itu mulai memiliki kesadaran mencintai dan mengutamakan bahasa Indonesia untuk mempertahankan dan melestarikan bahasa kita sendiri. Juga harus mulai membiasakan menulis kalimat caption dengan bahasa Indonesia yang baik dan yang benar. Jadi tidak akan ada lagi caption instagram yang memiliki ketidakefektifan kalimat.

\section{DAFTAR PUSTAKA}

Badan Pengembangan dan Pembinaan Bahasa. 2009. Undang-Undang RI Nomor 24 Tahun 2009. [Online]. Tersedia dalam http ://badanbahasa.kemdikbud.go.id/ lamanbahasa/sites/default/files/U U_2009_24.pdf. Diunduh pada 23 Agustus 2018.

Cahyono, Agung S. 2016. Pengaruh Media Sosial Terhadap

Perubahan Sosial Masyarakat di Indonesia. PUBLICIANA: Jurnal ilmu sosial dan ilmu politik diterbitkan oleh Fakultas Ilmu Sosial dan Politik, Universitas Tulungagung. Vol.9 No.1. [Online] Tersedia dalam http://www.jurnalunita.org/index.php/publiciana/art icle/view/79. Diunduh pada 23 Agustus 2018.

Chaer, Abdul. 2006. Tata Bahasa Praktis Bahasa Indonesia. Jakarta: PT Rineka Cipta

Istiqomah, Nurul. 2016. Analisis Variasi Penggunaan Bahasa Caption di Instagram. [Online] Tersedia dalam 
http://eprints.umm.ac.id/35976/1/ jiptummpp-gdl-nurulistiq-491681-pendahul-n.pdf

Kontesia. 2018. Apa Itu Caption Instagram. [Online] Tersedia dalam https://kontenesia.com/apa-itucaption-instagram/

Putrayasa, Ida B. (2007). Kalimat Efektif (Diksi, Struktur, dan Logika). Bandung: Refika Aditama.

Putrayasa, Ida B. (2010). Analisis Kalimat. Bandung: Refika Aditama.

Tim Depdiknas. (2012). Pedoman umum ejaan Bahasa Indonesia yang disempurnakan. Bandung: Yrama Widya.

Soedjito dan Djoko Saryono. (2014). Tata Kalimat. Malang: Aditya Media. 